\title{
Peran Komoditi Perkebunan Rakyat Unggulan Dalam Meningkatkan Pendapatan dan Pelestarian Lingkungan di Kabupaten Rokan Hulu
}

\author{
Kiagus Muhammad Zain Basriwijaya ${ }^{1^{*}}$ \\ Laily Fitriana ${ }^{2}$ \\ ${ }^{1}$ Fakultas Pertanian Universitas Samudra, Langsa \\ ${ }^{2}$ Fakultas Pertanian Universitas Pasir Pengaraian, Rokan Hulu \\ *email: zainkiagus@unsam.ac.id \\ Diterima: September 2020; Disetujui: Maret 2021; Dipublish: April 2021
}

\begin{abstract}
Abstrak
Penelitian ini dilakukan untuk mengkaji peran komoditi perkebunan rakyat unggulan dalam meningkatkan pendapatan masyarakat dan pelestarian lingkungan di kawasan Batang Lubuh Kabupaten Rokan Hulu. Metode penelitian dengan menggunakan analisis deskriptif dan location quotient (LQ), dengan data sekunder time series 2015-2020. Berdasarkan hasil penelitian disimpulkan, komoditi perkebunan rakyat unggulan yang terdapat di kabupaten Rokan Hulu terdiri atas 3 (tiga) jenis komoditi yaitu; komoditi karet, kopi dan kemiri, untuk mengembangkan komoditi perkebunan rakyat unggulan sangat diperlukan peran Pemerintah dalam upaya peningkatan produktifitas secara spesifik melalui berbagai program, pengembangan komoditi perkebunan rakyat unggulan akan berdampak pada peningkatan pendapatan masyarawat dikawasan Sungai Batang Lubuh di Kabupaten Rokan Hulu, selain sebagai sumber pendapatan masyarakat komoditi perkebunan rakyat unggulan ini berperan penting dalam pelestarian alam di kawasan sungai batang lubuh kabupaten Rokan Hulu. Berdasarkan hasil penelitian disarankan; pemerintah Kabupaten Rokan Hulu, harus melakukan peningkatan produktifitas yang lebih fokus pada komoditi perkebunan rakyat unggulan melalui berbagai program yang didukung dengan perbaikan teknologi usahatani dan teknologi budidaya, pengembangan infrastruktur, pemerintah Kabupaten Rokan Hulu, harus melakukan berbagai pelatihan kepada petani yang mengelola perkebunan rakyat, pemerintah Kabupaten Rokan Hulu, harus melakukan penyuluhan kepada masyarakat dalam rangka meningkatkan pendapatan masyarakat di wilayah ini, pemerintah Kabupaten Rokan Hulu, harus mendukung dan mengarahkan masyarakat dalam rangka pelestarian kawasan Sungai Batang Lubuh dengan berbasis kearifan lokal.
\end{abstract}

Kata Kunci : Komoditas Unggulan, Location Quotien (LQ), Rokan Hulu

\begin{abstract}
The research was conducted to assess role the people plantation commodities seeded to increase the people income and environment conservation in the Batang Lubuh River region in Rokan Hulu Regency. Research methodology using descriptive analysisi, Location Quotient (LQ) and Likert scale analysis. For $L Q$ analysis used scondary data time series 2015 - 2020. Based on the research done conclude: The people plantation commodities seeded than is in Rokan Hulu Regency consist the three types indipensable, that is Rubber, coffee and candlenut. To developing the people plantation seeded in.dispesable role of the government in an effort to increase produktivity specifically through various program. developeing people plantation seeded will impact on improving the income people in Batang Lubuh River region in Rokan Hulu Regency. Beside as a source of the income of the coomodities this seed play on important role in natural conservation and from tha analysis scale likert known level the role of coomodities seed of play an important role in increasing socioecomomic famers in Batang Lubuh River region in Rokan Hulu Regency. Beside the research suggested, The Government Rokan HuluRegency have todo productivity of people plantation through a variety os seed program by an improvement of the cultivation technology and farming technology and infrastructure development. The Regency have to do a variety of training for farmer who manage
\end{abstract}


people plantation. should do conselingto resident in order to increasing the incomeof the in this region the Rokan Hulu Regency. d) have to support and directing the community in order to preserve the region of Batang Lubuh River with local knowledge based.

Key Word: Commodities, Location Quotient (LQ), Rokan Hulu

\section{PENDAHULUAN}

Disamping perkebunan besar, bahwa perkebunan rakyat memegang peran penting sebagai sumber pendapatan masyarakat, kesempatan kerja, pelestarian lingkungan dan sumberdaya hayati. Usaha perkebunan rakyat merupakan kegiatan yang yang dilakukan petani dengan skala kecildengan pengelolaan secara tradisional dengan teknologi yang minim. Berbeda dengan pengelolaan perkebunan yang diusahakan perusahaan pemerintah/swasta, dengan sistem pengelolaan dan pengusahaannya dilakukan dengan bantuan teknologi modern.

Data BPS tahun 2020 menunjukkan luas lahan perkebunan rakyat di Propinsi Riau mencapai 1.083.268,79 ha atau hampir 55,55\% dari total luas perkebunan yang ada di Riau dengan produksi mencapai 6.889.228,39 ton. Perkebunan rakyat ini meliputi; komoditi karet, kemenyan, kopi, coklat, cengkeh, kelapa, kulit manis, vanili, kemiri, pinang, aren, tebu rakyat hingga tembakau artinya perkebunan rakyat ini memiliki peran penting sebagai sumber pendapatan masyarakat, sehingga perkebunan rakyat ini sangat potensial untuk dikembangkan hal ini dapat dilihat dari kontribusi luas lahan dan produksinya bahwa perkebunan rakyat ini tetap memberikan sumbangsih bagi pendapatan masyarakat bahkan pendapatan daerah.
Perkembangan luas areal dan produksi komoditi perkebunan rakyat ini mengalami peningkatan dari tahun ke tahun, misalnya pada Tahun 2016, komoditi karet memiliki luas lahan $8.279,76$ ha, naik menjadi $8.332,25$ ha Tahun 2019. Produksi komoditi ini pada tahun 2016 tercatat $4,332,25$ ton kemudian meningkat menjadi 4,661,84 ton tahun 2019 (naik 0,04\%) dari tahun sebelumnya (BPS Riau, 2020)

Kabupaten Rokan Hulu terdapat beberapa komoditi perkebunan rakyat yang berperan penting sebagai sumber pendapatan masyarakat diantaranya; karet, kopi, coklat, cengkeh, kelapa, kulit manis, nilam, kemiri, pinang, aren, lada, dan andaliman (Fitriana, 2018). Komoditi-komoditi ini memiliki perkembangan luas lahan yang bervariasi, misalnya komoditi karet rakyat tahun 2016 dengan luas lahan 655,97 ha mengalami penurunan menjadi 442,00 ha pada tahun 2019. Demikian juga dengan produksi komoditi ini tahun 2016 tercatat 707,74 ton dan mengalami penurunan menjadi 584,80 ton pada tahun 2019 (BPS Rokan Hulu, 2020). Hal ini menunjukkan bahwa perkebunan rakyat di Rokan Hulu masih sangat potensial untuk dikelola dengan baik, karena masyarakat dalam mengelola perkebunan rakyatumumnya masih menerapkan teknik yang sederhana dengan manajemen usaha yang belum efisien dengan system 
pengelolaan perkebunan secara tradisional. Untuk beberapa komoditi tertentu bibitnya diperoleh dari tanaman yang dianggab baik tanpa teknologi dan proses pembibitan yang sederhana, sehingga produktifitasnya rendah, kemampuan dan sumberdaya petani yang masih rendah.Berdasarkan uraian tersebut diataspenelitian ini dilakukan untuk mengkaji Peranan pembangunan pertanian berkelanjutan berbasis komoditi perkebunan rakyat unggulan sebagai upaya pelestarian kawasan Batang Lubuh di Kabupaten Rokan Hulu. Kegunaan penelitian ini adalah sebagai sumbangan pemikiran bagi pihak-pihak terkait mengenai peran komoditi perkebunan rakyat unggulan dalam meningkatkan pendapatan masyarakat dan pelestarian lingkungan di Kawasan Sungai Batang Lubuh Kabupaten Rokan Hulu.

\section{METODE PENELITIAN}

Penelitian ini dilakukan di kawasan sekitar Sungai Batang Lubuh Kabupaten Rokan Hulu yang ditentukan secara purposive dengan memilih lokasi penelitian secara sengaja dengan pertimbangan-pertimbangan khusus yaitu petani sawit yang tinggal di sepanjang sungai Batang Lubuh (Kuncoro, 2019). Data yang digunakan dalam penelitian ini adalah data sekunder 2015-2020 bersumber dari Badan Pusat Statistik (BPS) Rokan Hulu, Jurnal dan publikasi resmi lainnya yang berkaitan.

Penentuan sampel menggunakan simple random sampling yaitu sampel digunakan adalah $10 \%$ dari total populasi petani yang mengusahakan komoditi unggulan, yaitu 300 petani sehingga diperoleh sampel sebesar 30 responden. Adapun instrumen penelitian berupa angket yang berisi pernyataan terkait 3 indkator sosia ekonomi, yaitu Sosial, ekonomi dan budaya. Indikator ini yang menunjukan tingkat pendapatan meningkat.

Teknik analisis data yang digunakan dalam penelitian ini adalah metode deskriptif, location Quotient (LQ) dan metode kualitatif menggunakan skala likert. Metode deskriptif menjelaskan gambaran tentang bagaimana pengembangan dan perkembangan serta pelestarian ligkungan di kawasan peneitian.

Sedangkan Metode location quetion (LQ) untuk mengetahui komoditi perkebunan rakyat yang unggul didaerah penelitian dengan menggunakan nilai ekonomi komoditi perkebunan rakyat yang diteliti sebagai variabel yang dianalisis dengan mengacu pada formulasi sebagai berikut;

$$
\left.L Q=\frac{N k i W a / \text { Tnk } W a}{N k i S n / \text { Tnki Sn }} \ldots \ldots \ldots \ldots \ldots \ldots 1\right)
$$

Sumber : (Ismail, 2018)

dimana :

NkiWa : Nilai ekonomi komoditi i disuatu wilayah analisis

TnkWa : Total nilai ekonomi komoditi di wilayah analisis

NkiSn : Nilai ekonomi komoditi i secara nasional

TnkiSn : Total nilai ekonomi komoditi secara Nasional

Komoditi yang dianalisis dikategorikan menjadi 3 (tiga) kelompok berdasarkan nilai LQ-nya (Kuncoro, 2019) yaitu : a) apabila nilai $L Q>1$, maka 
tingkat spesialisasi komoditi lebih besar dikabupaten dibanding dengan komoditi yang sama di propinsi, b) jika nilai $\mathrm{LQ}<1$ maka tingkat spesialisasi komoditi tersebut di kabupaten lebih kecil dari komoditi yang

sama di propinsi, c) jika nilai $L Q=1$, maka tingkat spesialisasi komoditi tertentu di kabupaten sama dengan di tingkat propinsi.

Metode skala likert digunakan untuk mengetahui tingkat peran komoditi unggulan yang diteliti. Dalam mengetahui tingkat peran komoditi unggulanmenggunakan skoring data berupa skala ordinal, dengan 3 kategori. Kategori tersebut adalah jawabn angket dengan kategori kurang setuju dengan skor 1 , cukup setuju skor 2 dan sangat setuju skor 3 .

Skor dari responden kemudian dijumlahkan berdasarkan indikatornya dan kemudian di rata-ratakan.Sebelum penafsiran berada pada tingkatan peran maka ditentukan terlebih dahulu dengan menentukan skala intervalnya, menurut Mona (2021) sebagai berikut:

$C=$

$\frac{X n-X i}{K}$

Ket:

C : Interval Kelas

Xn: Skor maksimum

Xi: Skor Minimum

K: Jumlah Kelas

Interval kelas pada setiap kategori dihitung dengan formula tersebut sehingga diperoleh kelas interval sebesar 0,66 . Nila ini digunakan untu menyusun klasifikasi peran komoditi unggulan menurut kelas interval. Pada kategori kurang berperan inerval kelasnya berada pada rentang $1-1,66$, Kategori cukup berperan berada pada rentang 1,67 2,33 dan kategori sangat berperan berada pada rentang 2,34- 3 .

\section{HASIL DAN PEMBAHASAN}

Kabupaten Rokan Hulu dengan luas wilayah 2.021,8 $\mathrm{km}^{2}$ dengan jumlah penduduk mencapai 175.325 jiwa.Salah satu pilar pembangunan Kabupaten Rokan Hulu adalah terciptanya pertanian yang maju sehingga menjadi sektor andalan dalam menggerakkan perekonomian daerah. Sektor perkebunan terutama perkebuan rakyat seperti; karet, kemenyan, kopi, coklat, cengkeh, kelapa, kulit manis, nilam, kemiri, pinang, aren memiliki peran penting sebagai sumber pendapatan bagi masyarakat bahkan pendapatan daerah Kabupaten Rokan Hulu (BPS Rokan Hulu, 2020). Berdasarkan hasil analisis data dapat dilihat bahwa komoditi perkebunan rakyat di Kabupaten Rokan Hulu sangat potensial untuk dikembangkan dalam rangka meningkatkan pendapatan masyarakat dan pelestarian lingkungan. Data menunjukkan bahwa luas lahan komoditi mengalami pertumbuhan yang sangat signifikan sejak tahun 2015 hingga 2020 yang diikuti dengan perkembangan produksi, hal ini menunjukkan luas lahan komoditi pada peningkatan pendapatan masyarakat dan bagi pelestarian lingkungan di kawasan ini. Salah satu contoh Perkembangan luas lahan komoditi kopi yang dikelola masyarakat di Kabupaten Rokan Hulu pada Tahun 2016- 2020 sebagaima di sajikan pada Grafik 1. 


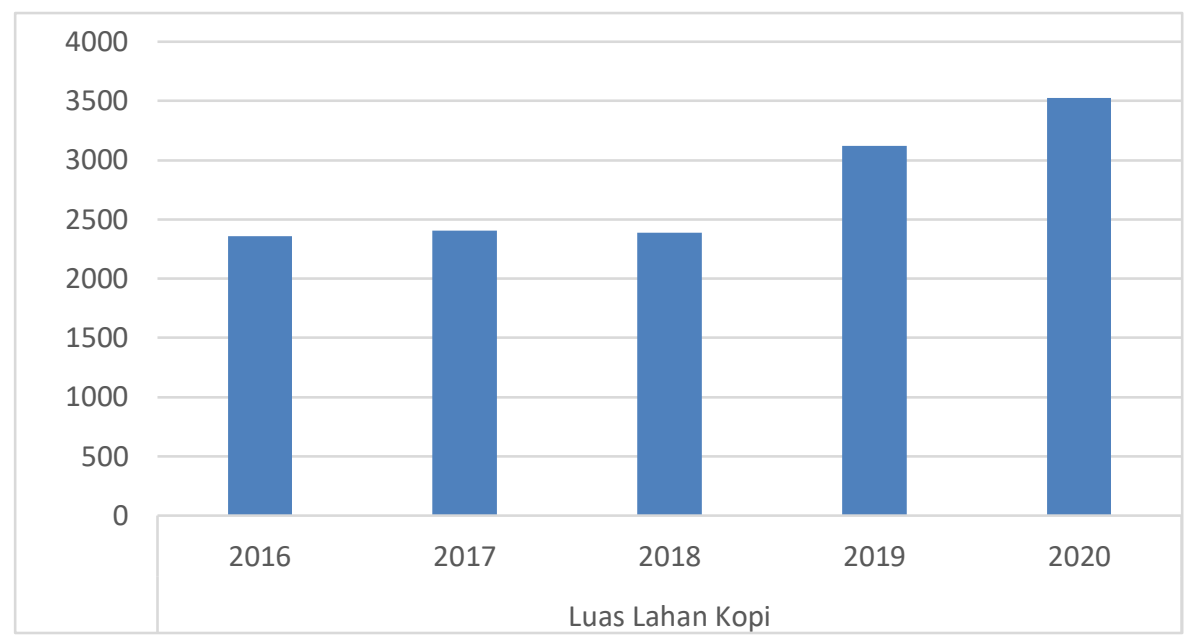

Sumber : Data sekunder diolah, 2020.

Grafik 1. Perkembangan Luas lahan Komoditi Perkebunan Rakyat Kopi Rokan Hulu 2016-2020

Disamping komoditi kopi terdapat komoditi perkebunan lain yang potensial di kembangkan di wilayah ini sebagaimana disajikan pada grafik yaitu komoditi karet dengan luas lahan yang mengalami perkembangan yang signifikan dan linier dari tahun 2016 hingga 2020. Perkembangan luas lahan ini diikuti dengan perkembangan produksi sehingga berdampak pada pendapatan masyarakat, demikian juga dengan beberapa komoditi lainnyajuga mengalami perkembangan luas lahan yang signifikan sejak tahun 2016 - 2020. Perkembangan luas lahan komoditi perkebunan rakyat ini akan berdampak pada upaya pelestarian lingkungan di kawasan ini sebagaimana pada Grafik 2.

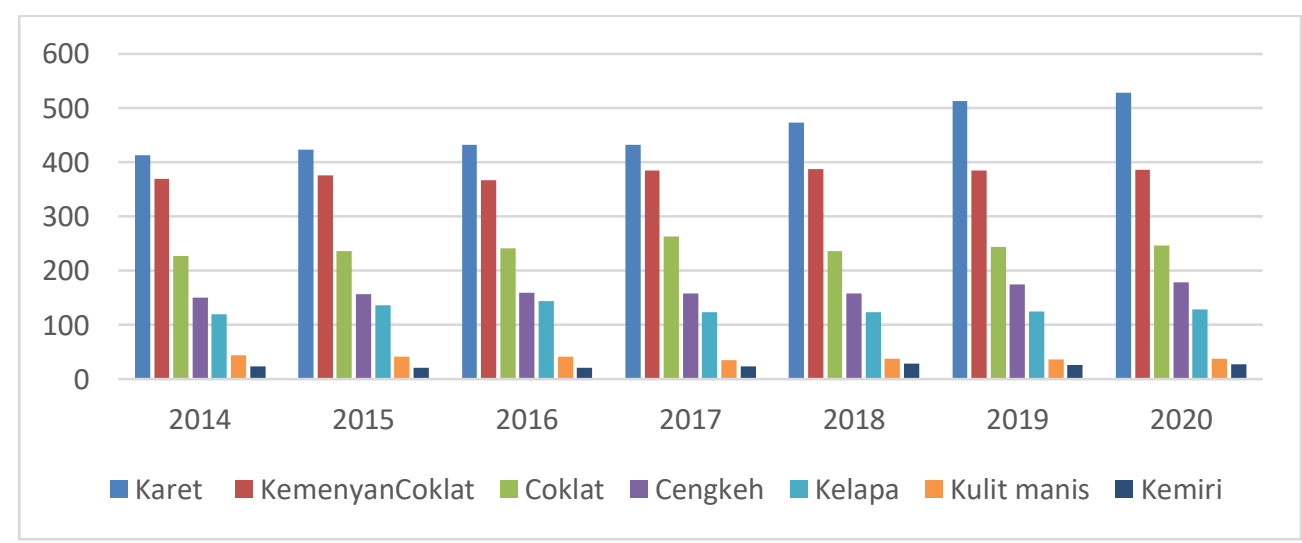

Sumber : Data sekunder diolah, 2020.

Grafik 2. Perkembangan Luas lahan Komoditi Perkebunan Rakyat di Kabupaten Rokan Hulu 2016-2020

Walaupun memberikan kontribusi besar terhadap pertumbuhan ekonomi, namun pemilihan jenis tanaman yang diusahakan ini hanya berdasarkan usaha turun temurun yang sudah dilakukan oleh orang tua terdahulu. Banyak tanaman perkebunan yang dibudidaya setiap kecamatannya. Namun tidak melihat potensi daerah dan strategi pembangunan komoditi berkelanjutan 
agar meningkatkan produktivitas dan efisiensi pengembangannya. Disamping itu permasalahan lainnya dalam pengembangan komoditi perkebunan

\section{Komoditi Perkebunan Rakyat Unggulan di Kabupaten Rokan Hulu}

Berdasarkan hasil analisis data dengan menggunakan metode Analisis masih dilakukan secara umum di semua daerah dan belum adanya spesifikasi komoditas berdasarkan potensi yang dimiliki oleh masing-masing daerah.

LQ diketahui beberapa jenis komoditi perkebunan rakyat unggulan di Kabupaten Rokan Hulu sebagaimanapada Tabel 1.

Tabel 1. Nilai LQ Komoditi Perkebun Rakyat di Kabupaten Rokan Hulu 2016-2020.

\begin{tabular}{lllllllll}
\hline \multirow{2}{*}{ No } & Jenis & \multicolumn{7}{c}{ Nilai $Q$ Komoditi Kebun Rakyat Kabupaten Rokan Hulu (tahun) } \\
& Komoditi & & 2016 & 2017 & 2018 & 2019 & 2020 & Keterangan \\
\hline 1 & Karet & 1,89 & 1,45 & 1,48 & 1,89 & 1,45 & 1,89 & Komoditi Unggulan \\
2 & Kemenyan & 0,45 & 0,45 & 0,45 & 0,65 & 0,78 & 0,75 & Komoditi Non unggulan \\
3 & Kopi & 1,97 & 1,46 & 1,65 & 1,76 & 1,45 & 1,39 & Komoditi Unggulan \\
4 & Coklat & 1,06 & 1,23 & 0,65 & 1,16 & 0,90 & 0,87 & Komoditi Non Unggulan \\
5 & Cengkeh & 0,10 & 1,54 & 1,98 & 0,90 & 0,89 & 1,54 & Komoditi Non Unggulan \\
6 & Kelapa & 1,65 & 0,89 & 0,87 & 0,76 & 0,76 & 1,45 & Komoditi Non Unggulan \\
7 & Kulit Manis & 0,30 & 0,40 & 0,20 & 0,10 & 0,21 & 0,32 & Komoditi Non Unggulan \\
8 & Kemiri & 1,98 & 2,40 & 2,30 & 1,15 & 1,98 & 1,98 & Komoditi Unggulan \\
9 & Pinang & 0,40 & 0,30 & 0,80 & 1,90 & 0,56 & 1,30 & Komoditi Non Unggulan \\
10 & Aren & 1,30 & 0,80 & 1,46 & 1,40 & 0,60 & 1,50 & Komoditi Non Unggulan \\
\hline
\end{tabular}

Sumber : Data sekunder diolah, 2020.

Berdasarkan hasil analisis data dengan metode LQ sebagaimana pada Tabel 2 diketahui bahwa komoditi karet sebagai salah satu komoditi perkebunan rakyat diwilayah ini memiliki nilai $L Q>1$ secara konsisten dari tahun 2015-2020 hal ini menunjukkan bahwa komoditi ini memiliki komoditi yang lebih besar di Kabupaten Rokan Hulu dibandingkan dengan Riau, artinya komoditi ini merupakan komoditi perkebunan rakyat unggulan di Kabupaten Rokan Hulu.

Disamping komoditi karet terdapat komoditi kopi yang memiliki nilai LQ > 1 secara konsisten dari tahun 2015-2020, dengan nilai $L Q>1$ hal ini menunjukkan bahwa komoditi kopi ini juga memiliki komoditi yang lebih besar di Kabupaten
Rokan Hulu dibandingkan dengan Riau, maka komoditi ini merupakan komoditi perkebunan rakyat unggulan di wilayah ini. Kemudian berdasarkan hasil pengolahan data sebagaimana padaTabel 1 komoditi kemiri juga memiliki nilai LQ>1 secara berturut-turut sejak tahun 2015-2020 maka komoditi ini memiliki tingkat yang lebih besar di Rokan Hulu dibandingkan dengan Riau artinya komoditi ini merupakan komoditi perkebunan rakyat unggulan di Kabupaten Rokan Hulu dan perkembangan nilai LQ ke tiga komoditi ini sebagaimana disajikan pada Grafik 3 .

Hal ini disebabkan rendahnya luas lahan komoditi perkebunan. Produksi pada tahun 2015-2020 sebesar 0,9 ton 
dan menurun pada tahun 2018 hanya mencapai 0,8 dan meningkat pada tahun 2019 menjadi 1 ton. Kurangnya luas lahan akibat banyaknya alih fungsi lahan. Penurunan produksi disebabkan turunnya luas lahan perkebunan.
Menurunnya luas areal perkebunan ini diduga banyak tanaman terserang hama dan penyakit, masyarakat beralih profesi dan menurunnya luas lahan dan juga produktivitas sehingga produksi rendah (Rosdah, 2017).

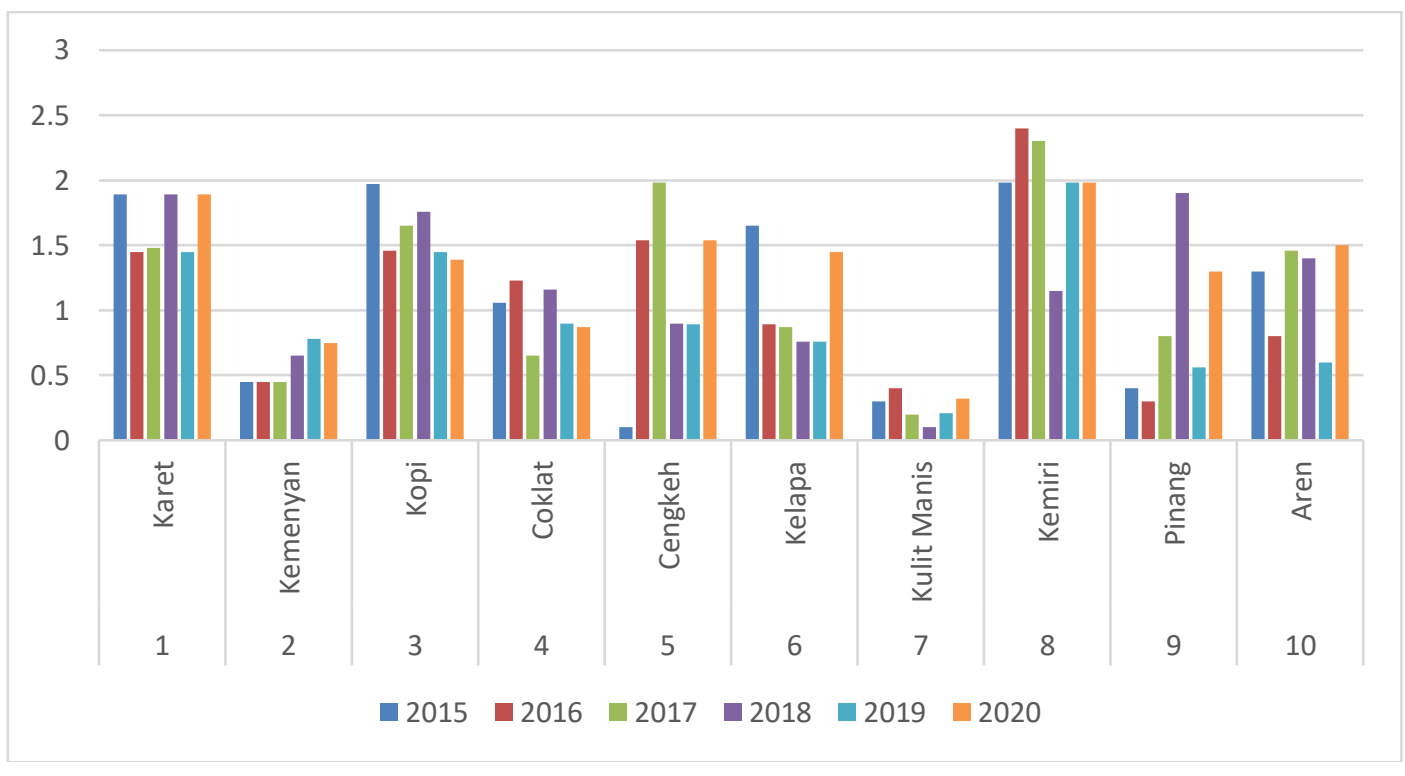

Gambar 3. Grafik Perkembangan Nilai LQ Komoditi Unggulan Perkebunan Rakyat di Kabupaten Rokan Hulu 2015-2020

Pengembangan Komoditi Perkebunan

Rakyat

Unggulan

Meningkatkan

Masyarakat

Berdasarkan hasil analisis data sebagaimana pada Tabel 2 diketahui di Kabupaten Rokan Hulu terdapat 3 (tiga) jenis komoditi perkebunan rakyat unggulan yaitu; komoditi karet, kopi dan kemiri dengan demikian pemerintah Kabupaten Rokan Hulu harus melakukan upaya peningkatan produktifitasnya secara spesifik melalui berbagai program peningkatan produktifitas yang tepat untuk meningkatkan pendapatan masyarakat.
Komoditi karet sebagai komoditi unggulan di Kabupaten Rokan Hulu sangat potensial dikembangkan untuk meningkatkan pendapatan masyarakat. Komoditi ini juga merupakan tanaman hutan industri secara ekonomis menguntungkan karena menghasilkan lateks maupun kayu sehingga meningkatkan produkstivitas lahan, bermanfaat terhadap pengembangan sosial dan peningkatan pendapatan masyarakat (Ditjenbun, 2020).

Hasil penelitian (Agustina, 2013) menyampaikan nilai ekonomis tanaman karet terletak pada kemampuannya menghasilkan lateks. Setelah berumur 4- 
5 tahun, tanaman karet dapat disadap.

Dengan teknik penyadapan yang baik, tanaman karet dapat disadap selama 2530 tahun (Rosdah, 2017). Jika diasumsikan produksi sleb petani per bulan pada tahun pertama sadap mencapai $80 \mathrm{~kg} / \mathrm{ha}$ dan tingkat harga di petani $\mathrm{Rp} 10.000 / \mathrm{kg}$, maka pendapatan per bulan dari hasil karet mencapai $\mathrm{Rp}$ 800.000/ha dan produksi sleb ini akan terus meningkat seiring dengan bertambahnya umur tanaman karet. Pendapatan bersih dari hasil penjualan kayu karet pada saat peremajaan bisa mencapai Rp3.869.700/ha.

Agustina (2013) menyampaikan biji karet sebagai hasil samping dapat dimanfaatkan sebagai pakan ternak dan industri cat, selain sebagai sumber benih untuk batang bawah. Jumlah biji yang dihasilkan dari satu hektare tanaman karet per tahun antara 337.000-451.000 butir atau rata-rata 394.000. Jika diasumsikan harga biji karet Rp.180/butir, maka petani akan memperoleh nilai tambah dari penjualan biji karet sebesar Rp35.520.000 dalam satu periode musim biji. Daun karet dapat juga diolah menjadi bahan kerajinan, dengan demikian seluruh bagian tanaman karet dapat dimanfaatkan untuk meningkatkan pendapatan petani.

Disamping komoditi perkebunan rakyat karet, kopi Kabupaten Rokan Hulu juga memiliki komoditi kemiri sebagai komoditi perkebunan rakyat unggulan yang sangat potensial untuk

Fitriana (2018) menyampaikan bahwa penyuluhan merupakan proses transfer ilmu pengetahuan dan teknologi yang bertujuan untuk meningkatkan dikembangkan sebagai sumber pendapatan masyarakatdi kabupaten Rokan Hulu. Hasil penelitian Defidelwina (2017) sebanyak 58,9\% masyarakat mengembangkan tanaman kemiri dalam kawasan Taman Kota Rokan Hulu. Tanaman kemiri di wilayah ini telah dikembangkan sejak Pemerintah Belanda dan sejak saat itu kemiri merupakan simbol status sosial dan sumber pendapatan masyarakat. Lebih lanjut (Agustina, 2013)menyampaikan ratarata pendapatan masyarakat mencapai Rp.8.836.376 per tahun.

Sehingga Pemerintah Kabupaten Rokan Hulu harus berperan dalam membantu masyarakat untuk mengembangkan komoditi perkebunan rakyat unggulan tersebut termasuk dalam menyediakan lahan dalam rangka peningkatan produksinya. Lahan merupakan tempat bergantung untuk memenuhi kebutuhan hidup petani dan keluarganya (Ismail, 2018) menyampaikan penggunaan lahan diartikan sebagai bentuk intervensi terhadap lahan dalam rangka memenuhi kebutuhan hidup petani melalui peningkatan produksi usahataninya.

Sejalan dengan itu (Basriwijaya, 2014) menegaskan bahwa kunci keberhasilan dalam peningkatan produktifitas komoditi tanaman unggulan harus didukung oleh beberapa faktor yaitu; a) perbaikan teknologi usahatani, b) perlunya pengembangan infrastruktur seperti; irigasi, lembaga penyuluhan dan sebagainya.

kemampuan masyarakat, terutama mengenai teknik bercocok tanam yang baik untuk meningkatkan produktifitas lahan garapan petani. Sejalan dengan itu 
pemerintah Kabupaten Rokan Hulu harus melakukan upaya terpadu dalam rangka peningkatan produktifitas komoditi perkebunan rakyat tersebut melalui penyediaan sarana produksi yang terjangkau, perbaikan teknologi budidaya dan pasca panen serta melakukan berbagai pelatihan kepada petani dalam mengelola perkebunan rakyat di wilayah ini, sehingga tingkat pendapatan masyarakat yang mengelola komoditi perkebunan rakyat mengalami perbaikan.

\section{Pengembangan Perkebunan Rakyat Unggulan Dalam Melestarikan Kawasan Sungai Batang Lubuh}

Sesuai dengan hasil analisis data sebagaimana pada Tabel 2 terdapat 3 (tiga) jenis komoditi perkebunan rakyat unggulan di Kabupaten Rokan Hulu yaitu; komoditi karet, kopi dan kemiri. Tanaman karet sebagai komoditi perkebunan rakyat, merupakan salah satu komoditas perkebunan yang berperan penting dalam reboisasi dan rehabilitasi lahan, karena sifatnya yang mudah beradaptasi terhadap lingkungan (Nur, 2014). Karet mempunyai kemampuan yang cukup baik dalam menciptakan lingkungan yang stabil, sehingga cocok untuk menggantikan vegetasi hutan tropis basah yang produktif, serta dapat dibudidayakan dengan olah tanah minimum (minimum land clearing atau minimum tillage).

Boerhendhy dan Agustina (2013) menegaskan energi yang dihasilkan tanaman karet, berupa oksigen dan biomassa dapat digunakan untuk mendukung fungsi perbaikan lingkungan seperti rehabilitasi lahan, mencegah erosi dan banjir dan menciptakan iklim yang sehat. Secara alami, tanaman karet setiap tahun mengalami gugur daun yang mampu menyuburkan tanah. Daur hidup demikian akan terus berulang selama satu siklus tanaman karet, paling tidak selama 30 tahun. Tanaman karet dalam satu siklus dapat mengikat $\mathrm{CO}_{2}$ udara rata-rata 23 ton/ha/tahun. $\mathrm{CO}_{2}$ dapat diubah menjadi bentuk organik penyusun jaringan tanaman seperti akar, batang, daun, biji, dan lateks ( (Rosdah, 2017).

Fitriana (2018) menyampaikan konservasi tanah dapat dilakukan secara teknis dan vegetatif. Konservasi tanah secara vegetatif dapat dilakukan dengan pembangunan hutan tanaman industri, yang bermanfaat untuk meningkatkan produktifitas tanah dan kualitas air. Pemanfaatan tanaman karet untuk pembangunan hutan tanaman industri telah dikaji tahun 1989. Dalam kajian tersebut kalayakan karet sebagai tanaman hutan industri ditinjau dari aspek keserasian ekologis dimana dapat menciptakan lingkungan yang sehat karena tanaman karet berfungsi sebagai sumber oksigen, pengatur tata air tanah, pencegah erosi dan pembentukan humus, sehingga akan meningkatkan produkstifitas lahan (Ismail, 2018).

Jika ditinjau dari segi vegetasi bahwa perkebunan rakyat karet dapat berperan sebagai hutan karet, karena akan berfungsi sebagai pencegah erosi dan longsor serta sumber flora. Daya adaptasi dan keragaman genetik karet yang tinggi memunkinkan dikembangkan pada lahan marginal dan kritis dikawasan sungai batang lubuh di Kabupaten Rokan Hulu, mengingat komoditi ini merupakan komoditi perkebunan rakyat unggulan 
dan mampu menghasilkan produktifitas yang meningkat dari 1,08 ton/ha pada tahun 2016 menjadi 1,32 ton/ha pada tahun 2017 dan 1,1 ton tahun 2018 (BPS Rokan Hulu, 2020).

Selain komoditi karet terdapat komoditi kopi sebagai komoditi perkebunan rakyat unggulan di Rokan Hulu dengan luas lahan 2,385.43 ha pada tahun 2018 dan produksi 3,064.84 dengan produktifitas 1,28 ton/ ha pada tahun 2019 luas lahan komoditi ini tercatat 3.522,7 ha dengan produksi $3.390,1$ ton dengan produktifitas 0,96 ton/ha, sangat potensial untuk dikembangkan sebagai sumber penghasilan masyarakat dan menjaga kelestarian alam.

Pengembangan

komoditi perkebunan rakyat unggulan di kawasan Rokan Hulu merupakan bentuk usahatani konservasi (Fitriana, 2018). Usahatani konservasi yang dilakukan masyarakat di kawasan ini sangat diperlukan untuk menunjang keberhasilan pembangunan kawasan hutan. usahatani konservasi pada dasarnya merupakan satu paket teknologi usahatani bertujuan untuk meningkatkan produksi dan pendapatan petani serta melestarikan sumber daya tanah (defidelwina, 2017)

Agustina (2013) menyampaikan bahwa perkebunan kopi yang terdapat di kawasan hutan lindung di Sumberjaya, memiliki peran penting dalam menjaga ekosistem alam dan mampu mengkonservasi tanah dengan baik. Dengan sistem perkebunan rakyat monokultur apabila terjadi hujan lebat, maka tajuk dan perakaran kopi berfungsi untuk melindungi tanah. Ketika tanaman kopi semakin besar maka fungsi perlindungan terhadap tanah semakin baik sehingga tingkat erosi tanah yang terjadi semakin menurun.

Kelembagaan dan kapasitas petani dalam sistem pemasaran. Konsep ini cocok diterapkan di kabupaten Rokan Hulu (Ismail, 2018). Mengingat bahwa pada tahun 2019 luas lahan komoditi ini mencapai 169,8 ha dengan produksi mencapai 103 ton dan komoditi kemiri komoditi unggulan di wilayah (Gunawan, 2015)

Agustina (2013) menyampaikan usahatani tanaman tahunan merupakan suatu model pendayagunaan lahan secara permanen dengan memanfaatkan lahan secara optimal sesuai dengan kondisi agroklimat dan budaya masyarakat setempat. Keunggulan tanaman tahunan sebagai tanaman utama dalam kawasan DAS adalah budidaya dapat menerapkan olah tanah minimal (minimum tillage) sehingga mencegah struktur fisik tanah. Sehingga dengan demikian Pemerintah kabupaten Rokan Huluharus berperan penting dalam membantu masyarakat untuk mengembangkan komoditi perkebunan rakyat unggulan tersebut termasuk dalam menyediakan lahan dalam rangka peningkatan luas lahan serta melakukan pendidikan, pelatihan dan penyuluhan sehingga kemampuan petani meningkat.

Mosher (1983) dalam Fitriana (2018) menyampaikan tingkat pendididikan mempengaruhi cara berpikir seseorang terutama dalam menganalisis suatu permasalahan. Seseorang yang berpendidikan baik akan mudah mengadopsi teknologi baru dan mengembangkan keterampilan serta 
memecahkan permasaahan, bahkan kecenderungan yang ada jika tingkat pendidikan seseorang semakin tinggi maka aka semakin responsif terhadap perubahan.

Saragih (2021) juga menyatakan bahwa tingkat pendidikan berpengaruh terhadap perilaku seseorang dalam menghadapi lingkungan, baik lingkungan fisik dan lingkungan sosial. Tingkat pendidikan diasumsikan berpengaruh terhadap cara berpikir seseorang dimana semakin tinggi pendidikan, maka makin banyak pengetahuan yang akan direfleksikan dalam tindakan termasuk didalamnya pengetahuan tentang pelestarian lingkungan.

Peran Komoditi Perkebunan Rakyat Unggulan Pada Kawasan Sungai Batang Lubuh Kabupaten Rokan Hulu.

Pengembangan komoditi unggulan dikawasan Sungai Batang Lubuh sedikit banyak sangat berperan dalam peningkatan pendapatan. Seiring dengan itu keadaan sosial ekonomi masyarakat menjadi lebih baik. Berdasarkan analisis skala likert yang dilakukan maka diperoleh hasil sebagai berikut:

Tabel 2. Nilai Peran Komoditi Perkebunan Rakyat Unggulan 2016-2020.

\begin{tabular}{llccc}
\hline No & \multicolumn{1}{c}{ Indikator } & Total Skor & Rata-rata & Kategori \\
\hline 1 & Sosial & 394 & 2,62 & Sangat berperan \\
2 & Ekonomi & 456 & 2,55 & Sangat berperan \\
3 & Budaya & 279 & 2,32 & Cukup berperan \\
\hline & Jumlah & $\mathbf{1 . 1 2 9}$ & $\mathbf{7 , 4 9}$ & \\
& Rata-rata & $\mathbf{3 2 6 , 3}$ & $\mathbf{2 , 4 9}$ & Sangat Berperan \\
\hline
\end{tabular}

Sumber: Data Diolah 2020

Berdasarkan tabel dapat dilihat bahwa secara keseluruhan nilai rata-rata skor berjumlah 2,49 yang menunjuk tingkat peran komoditi perkebunan rakyat unggulan berada pada kategori sangat berperan. Namun pada hasil analisis disetiap indikator, indikator budaya menunjukan kategori cukup memuaskan.

Penyebab indikator budaya memiliki tingkat peran berada pada kategori cukup berperan adalah semakin berkurangnya petani mengelola perladangan dan perkebunan secara bersama-sama. Banyaknya petani yang mengkonversi lahan mereka ke tanaman berkebunan. Disamping itu peningkatan perluasan areal komoditi perkebunan dapat memicu rusaknya sumber daya alam (Gunawan, 2015)

Secara nasional peranan subsektor perkebunan cukup penting yaitu menyumbangan 3,30\% terhadap PDB. Selain itu (Nur, 2014)peranan lan subsektor perkebunan secara nasional adalah sebagai penyedia lapangan kerja, penyedia bahan baku industri, meningkatkan devisa negara, dan memacu pertumbuhan produktivitas kualitas komoditi perkebunan (Ditjenbun, 2020).

\section{SIMPULAN}

Berdasarkan hasil analisis disimpulkan, a) komoditi perkebunan rakyat unggulan yang terdapat di kabupaten Rokan Huluterdiri atas 3 
(tiga) jenis komoditi yaitu; komoditi karet, kopi dan kemiri, b) untuk mengembangkan komoditi perkebunan rakyat unggulan sangat diperlukan peran Pemerintah dalam upaya peningkatan produktifitas secara spesifik melalui berbagai program, c) pengembangan komoditi perkebunan rakyat unggulan akan berdampak pada peningkatan pendapatan masyarawat dikawasan sungai Batang Lubuh Kabupaten Rokan Hulu, d) selain sebagai sumber pendapatan masyarakat komoditi perkebunan rakyat unggulan ini berperan penting dalam pelestarian alam di kawasan Batang Lubuh kabupaten Rokan Hulu. e) Komoditi perkebunan rakyat yang berada di kawasan sungai batang lubuh sangat berperan dalam meningkatkan pendapatan petani, hal ini dapat dilihat pada kajian analisis peran pada setiap indikator sosial ekonomi masyarakat di kawasan itu.

\section{DAFTAR PUSTAKA}

Agustina. (2013). Kajian Kelembagaan Dan Kemitraan Pemasaran Kayu Karet Di Propinsi Sumatera Selatan. Jurnal Penelitian Karet, 31(1), 54.

Badan Pusat Statistik . (2020). Riau dalam Angka. Riau.

Badan Pusat Statistik . (2020). Rokan Hulu Dalam Angka. Rokan Hulu.

Basriwijaya, K. M. Z.(2014). Hubungan karakteristik petani dengan produksi padi sawah di Desa Rambah Tengah Barat Kecamatan Rambah Kabupaten Rokan Hulu. Jurnal Penyuluhan, 2(2), 2.

Basriwijaya, K. M. Z. (2017). Potensi Pengembangan Agribisnis (Studi Kasus Hutan Rakyat Di Kecamatan Kandangan Kabupaten Temanggung). Sungkai, 16-29.
Defidelwina. (2017). Penilaian Kelayakan Finansial Kebun Karet Dan Kelapa Sawit Rakyat Di Kabupaten Rokan Hulu. Agri Ekonomi, 24(1), 21.

Ditjenbun. (2020). Peran Komoditi perkebunan dalam Perekonomian Nasional. Jakarta: Kementrian Pertanian.

Gunawan, I. (2015). Analisis Strategi Pengembangan Usaha Komoditas Unggulan Pertanian Di Kabupaten Rokan Hulu. Sungkai, 22.

Ismail. (2018). Sektor Pertanian Pengungkit Pertumbuhan Ekonomi. Jakarta: Kolom Ekonomi .

Jef Rudiantho Saragih, A. S. (2021). Komoditas Unggulan dan Potensial Sektor Pertanian Kabupaten Simalungun, Provinsi Sumatera Utara. Jurnal Agro Bali, 12-19.

Kuncoro, M. (2019). Metode Riset Untuk Bisnis dan Ekonomi. Jakarta: Darussalam Press.

L Fitriana, KMZ Basriwijaya, Ikhsan Gunawan. $(2018,2)$. Pengaruh Faktor Fisik Dan Sosial Perencanaan Pertanian Untuk Meningkatkan Pendapatan Masyarakat Dan Pengembangan Wilayah Di Rokan Hulu. Seminar Nasional Ekonomi Produksi Pangan UMY (p. 44). Solo: Universitas Muhammadiyah Yogyakarta.

Lis Ria Arzika, R. R. (2020). Bentuk Interaksi Sosial Masyarakat Pribumi Dengan Masyarakat Pendatang Di Desa Tambusai Utara Kecamatan Tambusai Utara Kabupaten Rokan Hulu. Jurnal Bakoba, 13-20.

Nur, J. A. (2014). Partisipasi Masyarakat Dalam Rehabilitasi Lahan dan Konservasi Tanah (RLKT) di Sub Das Keduang Kabupaten Wonogiri. Jawa Tengah. Jurnal Penelitian Sosial Ekonomi Kehutanan, 11(3), 3.

Rosdah. (2017). Kearifan lokal masyarakat Sialang Jaya kecamatan Rambah Kabupaten Rokan Hulu. JOM Fisip Universitas Riau, 4(1). 
Jurnal Agrica Vol.14 No.1/April 2021

Available online http://ojs.uma.ac.id/index.php/agrica 10.31289/agrica.v14i1.4278

Sepri, Mona. (2021). Pengaruh Fluktuasi Harga Terhadap Kesejahteraan Petani Karet Desa Rokan Timur Kabupaten Rokan Hulu Ditinjau Dari
ISSN 1979-8164 (Print) ISSN 2541-593X (Online)

Ekonomi Syariah. Pekanbaru: Universitas Islam Negeri Sultan Syarif Kasim Riau 